\title{
THE ROLE OF CRUISING TOURISM IN TOURISM DEVELOPMENT OF SPLIT
}

\author{
MILI RAZOVIĆ \\ The University of Zadar, CROATIA \\ e-mail: mrazovic@unizd.hr; milirazovic@gmail.com
}

\section{KEYWORDS ABSTRACT}

cruise tourism, tourism demand, tourist destination, tourism supply

The city of Split is increasingly showing its cruising valorisation opportunities thanks to its geocommunication position, harbour infrastructure, cultural and historic heritage and the diversity of its tourism supply. Cruising tourism, as a form of modern tourism receives characteristics of strong element of tourism development in certain tourist destination. City of Split, along with some other ports in the Mediterranean, base its development opportunity also on the development of cruising tourism. It is known that cruising tourism has a positive effect on economic growth, image and development of tourist destination, while disadvantages of cruising are its' impact on local residents, stationary tourists and environment. The increase in both the number of cruise liner arrivals and tourists visiting a particular port creates the presumptions for the development of special forms of tourism supply and for its valorisation outside the main tourist season. Investing in new reception facilities in port aquatorium of the city of Split creates new possibilities for acceptance of ships with greater capacity. This creates new opportunities for increasing of cruise ships arrivals and increasing of tourist visits of Split tourist destination. Joint actions of local authorities and all operators of tourism offer can contribute so that Split tourist destination becomes recognizable as an international destination of cruising tourism. The main goal of this paper is to show the impact of cruising tourism on the improvement of brand image of Split and impact on prolongation of tourism season of Split tourist destination.

This paper particularly evaluates the contribution and impact of cruise tourism in the overall development of tourism and the positive economic effects of tourism on the city of Split.

\section{Introduction}

The development of cruise tourism has been impressive in two recent decades. The demand for cruising is now quadrupled. In 1990 there were 4.5 million passengers on cruise liners and in 2013 the number was 21.3 milion (European Cruise Council and Business research \& Economic advisors). 
The phenomenon of growth of the cruise market in the recent two decades is becoming increasingly complex. In cruise tourism there is a connection and correlation between holidaying and work, because it is organised on both the mainland and the sea, and under the jurisdiction of local, national and international authorities (Chin, 2008).

Cruise liners are like cities where production and consumption are carried out simultaneously, and where the location is not fixed. They are floating enclaves for holidaying - floating destinations for the travel between the ports of embarkation and disembarkation. As a result of globalisation, cruise companies look like world cities where differences are reduced among the countries with cruise tourism (Weaver and Duval, 2008).

Cruise passengers have the opportunity to consume new forms of experience ranging between the cosiness and the safety of home, yet far away from home (Chin, 2008).

Cruise liners replace the characteristics of one's own home, and the port being visited is a temporary environment with additional facilities of physical, historical, and social characteristics.

The cruising industry requires both co-ordination and integration, because it has become an important factor in the international business. The city of Split as a seaport in its natural environment, indented coast, hinterland resources and colouring, numerous cultural and historical localities of great value, with all the preconditions to develop into one more unavoidable cruising destination on the Croatian side of the Adriatic. However, to become even more attractive for the demanding cruise tourism, certain activities should be done in Split. Apart from accommodation port capacities the entire supply improvement requires certain activities to satisfy the needs of cruise tourists. In this way cruise tourism would have a higher economic effect. Improvement of the offer standard and special features that are a prerequisite for an increase in the number of arrivals of ships and visits of tourists on a cruise, cruise tourism will contribute to the higher economic impacts of tourism of Split.In addition, the city of Split will be positioned as a cruise destination in the international tourism market. This paper defines suggestions for improvement of the supply, suggestions for satisfying the needs of tourists on cruises in Split as well as suggestion for increasing the total economic impact of cruise tourism on the tourism offer of the city of Split.

\section{Main characteristics of cruise tourism}

Cruise tourism is a new form of tourism in comparison to other forms of tourism. Its development started in the mid 1960s, in parallel with the development of mass tourism. It all started when the first ship (the Oceanic), built exclusively for cruising (North America) entered the service in 1965, which is considered by some analysts to be the beginning of the modern cruise. The true development of cruising as the product for mass tourism started after the 1960s. Cruising tourism is a form of travelling on a vessel that lasts from 7 to 30 days. The vessel usually consists of accommodation facilities, catering facilities with food and beverage services, facilities for sport and recreation, entertainment facilities and visits to the locations - harbours - which in its narrow or wider area have natural and cultural and historical sights. The boat on which cruising journey takes place is considered as the primary destination, and all other destinations that are visited are considered as 
secondary destinations. Cruising tourism has an impact on secondary destination because it causes social, economic and environmental effects.

The sociological effects are those effects through which cruiser tourism affects the local people. Economic effects affect the economy, the employment and the budget of the local community. Ecological effects of cruise tourism particularly emphasize the importance of sustainable tourism development and the negative consequences that this kind of tourism has on the environment.

The cruise product can be understood as the correlation of two forms of tourism on the ocean and the mainland, the 'institutional holiday' used by passenger-tourists (Britton, 1991; MacCannell, 1989; Urry, 2002).

In this way, mass tourism market of cruising is becoming a strong irresistible desire which was defined by Ritzer and Liska (1997) as four principles: predictability, efficiency, calculability, and control in everyday life, particularly of the middle class in the USA.

According to Weaver and Duval (2008) cruise tourism is characterised by specific features. Firstly, cruise tourism is becoming the mass market of tourist travel. The mass tourism growth of cruise tourism is connected to the intensive development of mass production and mass consumption, as well as of mass tourism. Secondly, specificity of the cruise market is the connection among various brands and corporations for the cruise travel. Big cruise companies use merge strategies in their future growth strategy. By diversification of their operation, cruise companies research new opportunities in emerging market segments. Thirdly, globalisation and transnationality make an impact on cruise companies, negotiate and resolve the problem of employment that goes international. Fourthly, an established information system for the cruise is an example of international business operations. Fifthly, activities of the social responsibility of cruise companies are defined. Cruise tourism clearly represents and marks the nature of development, management and marketing of cruise companies, in the globalization of tourism. Cruise companies adapt their products by the size, taste and preferences to a growing number of tourists that are going on cruising for the first time.

Cruises are getting shorter, ships are getting larger, and number of cruise lines are increasing. A cruise liner resembles a hotel complex, a tourist resort, supplying lots of services apart from accommodation such as entertainment, sports activities and the like. In a cruise travel arrangement, the ship connects the airplane (transportation) and the port of embarkation (arrival) and disembarkation (departure). This is the so-called fly-cruise concept, in fact a package tour which is cheaper, and is sold as a product of entertainment and romance (Dickinson, Vladimir, 1997). The fly-cruise concept offers the passengers new benefits.

MacCannell (1989) claims that cruise tourists, no matter what their opportunities may be in differentiating of the real and the authentic 'on stage', will always choose authenticity in the nature and in level of satisfaction of their holiday needs. The strategy of the cruise product of satisfaction in the creation of travel should be directly linked to the subjective thinking and knowledge of the cruise customer-tourist. The cruise as a holiday reflects on the feelings and knowledge of customers' thoughts on and/or expectations of the journey (Chin, 2008). 
Cruise liners have supplied a model of alternative attractions as a response to mass tourism because what cruise tourists only need is the use of foreign exchange assets during their short stay in a port of call, a visit (Cartwright, Baird, 1999). Cruise liners connect the idea, function and practice, via the sea and ports, and become a 'tourist resort' of the twenty-first century (Chin, 2008).

Wood (2004) divides mass market of cruising into three segments.

Firstly, ships offering a discount are a typical supply based on the crew's kindness. Secondly, the "modern" segment is included in the supply of most cruise companies. These ships are perceived as a "floating destination" or a "floating resort". (Teye, Leclerc 1998) Their general characteristic is a wide variety of services, comfort and activities on the ship deck. Thirdly, the segment of 'awards' more and more address a higher market level i.e. of higher purchasing power consumers, and at elderly consumers. Peculiarities of 'awards' for cruising address particular destinations or ports.

Cruise supply comprises elements of a package tour, and it is in direct competition to the market of mass package arrangements of the tourist destinations themselves (Dickinson, Vladimir 1997). Cruise journeys are becoming a significant part of international tourism on a global scale.

The cruise liner per se is a certain destination. However, the cruise arrangement refers to the area where the cruise liner cruises. The cruise as a tourist destination is marked by the natural beauty of the area, its cultural and historical sights and the specific local life. From the standpoint of cruise tourists, the supply comprises the cruise liner and the supply in a destination/port of call, including its functional environment as well, plus the tourist supply of a wide range of products and attractive sites. The tourist chooses cruise liner and destinations of call (i.e. itinerary) on the basis of supply integrally offered by the cruise company. Cruise companies include destinations in their itineraries, i.e. ports of call and ports of departure, mainly based on the attractiveness of ports of call. This includes a possibility of additional income for the cruise liner company from trips and organised visits for the cruise tourist in a destination, and based on the complete characteristics of the supply in the related ports (Studija, 2007).

Croatia, with its supply for cruise liners visits on their international journeys, primarily addresses directly cruise companies, and only then, indirectly, the emitive tourist markets, Croatia promotes its own total tourist supply while the cruise supply is promoted by the cruise company.

\section{Split as a cruise destination}

The entire supply of Croatian destinations for international cruising comprise of: 1) the port that can accommodate a cruise liner, 2) the destination with a port nearby, which should be attractive enough for tourists' visits, 3) other destination supplies, of which the most important for a cruise company is the supply of trips and of organised sight-seeing of towns and cities (Studija, 2007, p. 42),

The city of Split is a part of the entire supply of Croatian destinations for international cruise journeys. 
Split is the second biggest city (population of 220,000) in the Republic of Croatia. It is an important centre of industry, transportation, commerce, tourism and culture on the Croatian part of the east Adriatic coast. Tourist supply of Split and its surroundings is its rich cultural and historic heritage. The area could be called the UNESCO-region, with the core and origin of Split i.e. Diocletian's Palace, the historical core of Trogir, and the "Ager" i.e. the Stari Grad Field on the island of Hvar. Moreover there are nonmaterial phenomena such as the knight game of Sinjska alka in Sinj, the lace of Hvar, and the procession on Hvar called Za križem, and a type of singing called ojkanje.

Another tourist attraction of the Split area is the archaeological site of Salona, the Archaeological Museum and Meštrović Gallery in Split, the fort of Klis, the Cetina River canyon and the town of Omiš, the picturesque hinterland of Dalmatinska Zagora with cultural and historical sites and the local domestic contents of Sinj, Trilj, Vrlika, Imotski and Vrgorac, the Central Dalmatian archipelago with the specifities of the islands of Brač, Hvar and Vis, and the attractive Makarska Riviera and the mountain of Biokovo. Its geo-communication makes Split an important centre of maritime transport. Split is the second biggest port in Croatia and the third biggest passangers port in the Mediterranean, where both cruise and cruise-tourist transport are important and have a significant role in operations and development of the port and city of Split.

Table 1. Traffic of tourists and cruise liners on cruise journeys in the port of Split

\begin{tabular}{ccc}
\hline Year & No. of calls & No. of tourists \\
\hline 2002 & 82 & 20,616 \\
2003 & 141 & 46,105 \\
2004 & 132 & 34,134 \\
2005 & 183 & 47,315 \\
2006 & 162 & 46,999 \\
2007 & 185 & 99,281 \\
2008 & 256 & 121,525 \\
2009 & 232 & 131,833 \\
2010 & 258 & 169,847 \\
2011 & 234 & 181,963 \\
2012 & 269 & 245,451 \\
2013 & 235 & 189,107 \\
\hline
\end{tabular}

Source: Port Authority, Split.

In the last 12 years the number of cruise calls at the port of Split has increased by more than 3 times and the number of cruise-tourists visiting Split has increased by more than 9 times (Table 1). This shows an indicative potential of the city of Split to turn into a cruise destination of a significantly higher level in the international competition than now. Regardless of the evident continuous growth of tourists on cruises coming to Split there are obvious insufficiencies and limitations to intense growth in this kind of tourism. This refers to the lack of operative coast and the ability of simultaneously docking a larger number of boats and a larger capacity for cruise liners. The location 
of the port of assessment contributes to slowing down the arrival of cruise tourists to Split as it is located in the centre of town which deters accessibility to other means of transport for trips and transfers.

There is particular obstacle because there is no single concept and communal action by all relevant institutions and organisations responsible for development that could support incentives for the development of cruising tourism more strongly and its' substantial contribution to the economic impacts of tourism in the city of Split. For this, a greater level of connection among town ports, shops, cultural institutions and the entire tourist sector could create a diverse and quality supply which would satisfy a wide range of the needs of the tourist on cruises that come to Split.

It is necessary to undertake a range of measures and activities to improve conditions which would in turn improve cruising tourism in Split. In that case Split can affirm itself and become more attractive on the cruising market.

\section{The influence of cruising tourism on the development of the tourism of the city of Split}

Cruising tourism of Split, as a form of modern tourism, achieves continuous growth mainly due to demand for this type of tourism in the Mediterranean and due to good cooperation with the international cruise companies that include the port of Split in their travel programs.

However, as well as the whole development process of tourism, this type of tourism has also number of development dilemmas. This particularly applies to the role of local stakeholders in the development of cruise tourism as well as on the representatives of tourist agencies, caterers, carriers, shops, cultural institutions, social tourism organizations and local residents.

In the clarification of the role of local stakeholders in the development of cruise tourism and the role of cruise tourism in the development of tourism of Split, a specific research was conducted, which is presented in this paper. Research starts from the main hypotheses: cruising tourism does not affect the development of modern tourism of City of Split. The research was conducted in October and in November 2014, on a sample of 100 respondents, representatives working in the area of the City of Split. The most important facts of the study are listed in the following presentations (Figure 1).

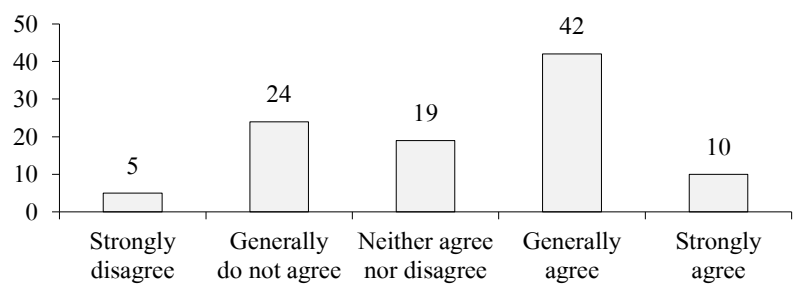

Figure 1. The assessment of cruising impact on tourism seasonality in Split (\%)

Source: author's research. 
More than half (52\%) of respondents ( $42 \%$ generally agree and $10 \%$ strongly agree) accept the claim that the cruise tourism is responsible for extension of the tourism season in Split and for the creation of year-round tourist business. The increase in cruise ship visits the off season and achievement of better tourism results in May, October and November clearly shows that cruise tourism does not operate on the principle of seasonality and that affects on the extension of the tourist season of Split.

The impact of cruise tourism on the development of year-round business in Split is evident through continued operation of restaurants, souvenir shops and other facilities that provide offer for cruiser tourists, which directly influence on the employment and incomes of the local community.

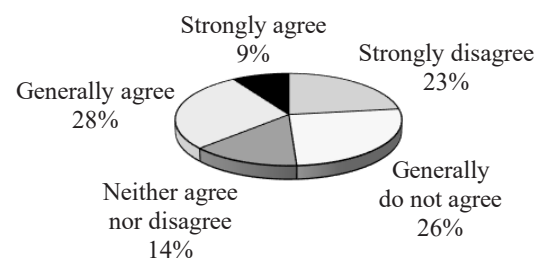

Figure 2. The impact of tourists from cruise ships on downtown that causes a reduction in number of stationary tourists and leaves a negative impression of overcrowding Source: author's research.

According to the Figure 2, especially interesting are the answers of 100 of respondents (stakeholders in the tourism of Split) on the claim that a large concentration of tourists from cruise ships in downtown cause escape of stationary tourists and leave a negative impression of overcrowding. With the above mentioned statement, $37 \%$ of respondents agreed ("generally agree" and "strongly agree") while $49 \%$ of respondents did not agree ("generally do not agree" and "strongly disagree"). It is obvious that there is a special attitude of local stakeholders in tourism on cruise tourism (nearly $50 \%$ of respondents) and it is considered the culprit for reducing of the attractiveness of the city and a nuisance for stationary tourists and tourists of other forms of tourism. Keeping in mind the economic impacts that cruise tourism brings to cruise destinations and the possibility that these economic effects become more significant, it is necessary to introduce systematic management of cruise tourism and organization of large group tours for cruise tourists in the Split town center.

Research results indicate the division of attitudes ( $40 \%$ agree and $41 \%$ disagree) in terms of the claim that the city of Split has no adequate offer for tourists from the cruise ships (Figure 3). City of Split has a large number of tourist and catering facilities such as restaurants, cafes, fast food and souvenir shops, but there is not enough additional facilities. After sightseeing of the town centre, which takes 1 hour and 30 minutes, tourists from the cruise ship can have lunch or a drink that takes additional 1 hour. 


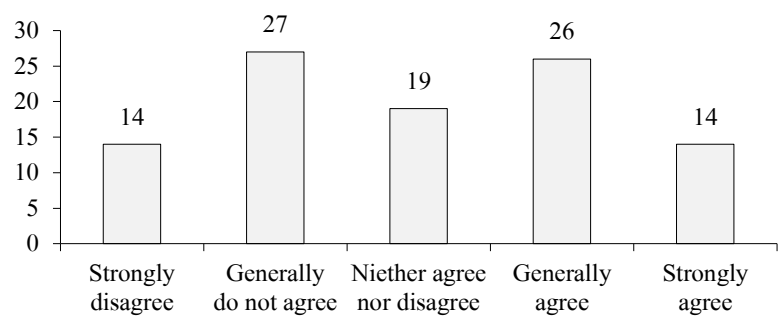

Figure 3. Inadequacy of Split's cruise tourism offer (\%)

Source: author's research.

Tourists have more than 3 hours for shopping, visiting museums or walking. This is the basic offer in the town center, that may be interesting to tourists from cruisers who are visiting for the first time Split. Therefore, it is necessary to complement the tourist offer of Split with additional facilities (sales of luxury goods, an organization of special event eg. folklore) that would become attractive for cruise tourists but also create additional economic impact of cruise tourism in the the City of Split.

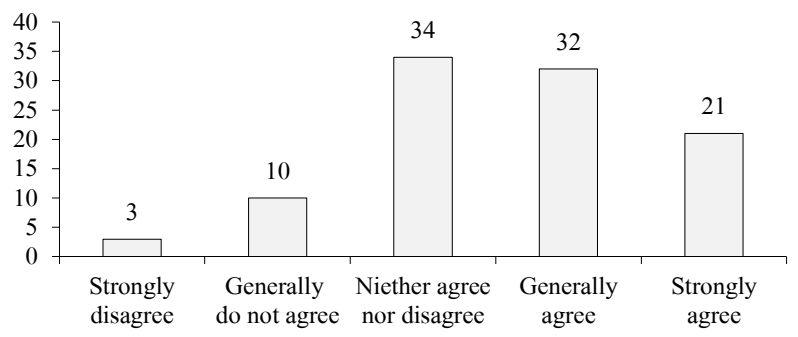

Figure 4. The possibility of the City of Split for response on trends in demand growth in international tourism (\%) Source: author's research.

Research results have proven that the City of Split, as a cruise destination, can successfully respond to trends in demand growth in the international cruise tourism (Figure 4). This confirms the completion of the project of construction of 2 external docks for cruise ships in 2016 when the port of Split will be able to accommodate more cruise ships and thus tourists. Therefore, the additional marketing activities and increase in supply are necessary to achieve the best possible satisfaction and consumption of cruise tourists during their stay in the City of Split. There is also assumption that through cruise tourism, tourist offer can get better valorisation and increase in economic effects on tourism of Split.

For relevant research in data processing through inferential statistics are being used chi-square test to try to prove the justifiability or the unjustifiable nature of the hypothesis: Cruising tourism 
does not affect the development of modern tourism of the City of Split. In the questionnaire, which was the main instrument in the collection of data needed for the research, questions were designed to provide the results that are easier to accept or to reject the hypothesis.

Based on the results from the questionnaire, for proving this hypothesis, a set argument is used: Cruising tourism is the fastest growing form of tourism in the City of Split. For the observed frequencies (fo, fo1, fo 2 , fo 3 ...) are used results of the stated questionnaire questions, while the expected frequency ( $\mathrm{ft}, \mathrm{ft} 1, \mathrm{ft} 2, \mathrm{ft} 3$...) were given by the rules of probability. Thus, the questionnaire was attended by 100 respondents, each survey question has five choices, therefore, the expected frequencies: $100 / 5=20$, that is, equal probability for any answer is the frequency 20 (Table 2).

Table 2. Received answers to the questionnaire and the expected answers

\begin{tabular}{ccccccc}
\hline Freq. & A & B & C & D & E & $\sum$ \\
\hline fo & 7 & 15 & 29 & 43 & 6 & 100 \\
$\mathrm{ft}$ & 20 & 20 & 20 & 20 & 20 & 100 \\
\hline$\sum$ & 27 & 35 & 49 & 63 & 26 & \\
\hline
\end{tabular}

Answers: A - strongly disagree, B - generally do not agree, C - neither agree nor disagree, D - generally agree, E - strongly agree

Source: author's research, Šaban (2015).

Table 3. The calculation of chi-square

\begin{tabular}{rrrrc}
\hline fo & $\mathrm{ft}$ & fo-ft & $(\text { fo-ft })^{2}$ & (fo-ft $)^{2} / \mathrm{ft}$ \\
\hline 7 & 20 & -13 & 169 & 8.45 \\
15 & 20 & -5 & 25 & 1.25 \\
29 & 20 & 9 & 81 & 4.05 \\
43 & 20 & 23 & 529 & 26.45 \\
6 & 20 & -14 & 196 & 9.8 \\
\hline
\end{tabular}

Source: author's research, Šaban (2015).

The resulting $\chi^{2}$ is 50 , which means that the hypothesis is not accepted (Table 3 ). In other words the hypothesis that: Cruising tourism does not affect the development of modern tourism city of Split is considered to be unfounded and rejected. Indeed, research shows that cruising tourism actually affect the development of modern tourism city of Split. The presented results show the fact that cruising tourism is one of the main factors of tourism development of the City of Split. However, research suggests that with the development of cruising tourism, development of the overall tourism offer needs to be harmonized, in order to obtain even higher degree of satisfaction of tourists' needs and increase of contribution of cruising tourism in the overall economic impact of tourism of City of Split. 


\section{Measures and actvities for the valorisation of split as a cruising destination}

According to the Study on Sustainable Development in the Development of Cruising Tourism in Croatia, in 2017 the City of Split will be visited by 500 thousand cruise tourists. This number is 4 times bigger than in 2009 (Study, 2007, p. 148). These predictions indicate the need of increase of activities in the aim of accelerating the development of Split as a cruising destination.

The starting point for the development of cruising tourism in Split is the creation of a singular concept of development for this form of tourism in the City of Split and Split-Dalmatia County. It is necessary to define clearly all participants' activities and duties that need to be fulfilled in this developmental project. Above all, this concerns the Town Administration, County, Port and Port Authority as well as business subjects from the areas of transport, retail and the public and private sector of tourism. The geographical and geo-communicational position of the town and the port of Split, aquatorium, natural resources, coast indentation, cultural and historical heritage, the proximity of the airport, its mid position on the route of sea navigation on the Adriatic are the diversity of tourist supply are preconditions which must be activated in Split, in order to hold more attractive position on the cruise tourism market. In the existing space of the port, there is capacity to dock cruise liners. However, particular developmental opportunity would be created with construction of an external pier in the south east part of the port as well as construction of terminal for tourists from cruise ships. All this would increase the port's capacity. With construction of additional port capacities, the existing potential of the port could be used better with involvement of human resources in the transport and tourism sector. This is in particular related to the pre and post season period when tourist and other receptive capacities are used minimally.

Together with increase of docking capacity of the port, it is necessary to present a new concept of the City of Split as a cruising destination. The city centre should increase the offer in retail, shopping and hospitality services. Also, city centre should have more different cultural facilities that would attract tourists from cruise ships. Following above mentioned, the consumption of cruise tourists in Split would increase, as well as the economic effect in this form of tourism. The affirmation of Split as a cruise destination is a special duty of local travel agencies. Considering the need of cruise tourists for trips on the mainland and around the port of call, the task of local travel agencies is to organize trips that would present culture and heritage to cruise tourists. The creativity and operative sense of local tourist agencies, that can create diverse trip programmes upon would motivate cruise tourists to use agencies' services and thus contribute the increase of use of tourism offer and increase the economic effects from cruise tourism. Considering the value of archaeological localities and diversity of the cultural-historic heritage and institutions in the City of Split and its nearby surroundings (Diocletian's Palace, Salona, Trogir, Klis, Meštović Gallery, Folklore, Theatre), it is necessary to create a plan and special operative programme that would increase their involvement in the tourism offer in cruising tourism. Also, it is necessary to create and activate special advertising activities to affirm this part of offer, so it can become one of the main reasons for cruise tourists for coming to Split. 
Considering the needs of tourists on cruises, it is also necessary to set up a special programme, that would be adaptable to the cruise tourists during their stay in Split and its' area. Implementers of those activities should be tourist offices, culture institutions and organisations, travel agencies, and business subjects from hospitality, retail and transport.

Those programmes or 'products' are designed to fulfil 5 to 7 hours long tourist stay on a cruise stay in Split. Therefore, one programme would be focused on sightseeing of Diocletian's Palace, Archaeological Museum, Art Gallery, Split's Town Museum, Meštrović Gallery, Marjan Hill with a compulsory visit to the production and retail of original products for souvenirs together with wine and food tasting experience.

The other programme would thematise particular forms of culture such as discovering every corner of Diocletian's Palace and organisation of Diocletian's Days, days when tourists can experience cuisine from that time. A special programme with would also be theatre experience with the operetta production of 'Mala Floramy' or Dalmatian a cappella singing.

Even though the programme of sightseeing Salona and the town of Trogir exists, it is still a very different concept, which besides sightseeing archaeological localities and cultural-historic monuments, offers more significantly cultural experience and the opportunity to buy original products and enjoy the local cuisine. Special programmes could valorise the specifities of the Split region. One programme is related to trips to the Cetina River with its active holiday activities (canoeing and rafting) all together with the opportunity to buy original products and tasting of the local food and wine. The same programme can be located near Biokovo Mountain where the flora and fauna can be experienced, active holidaying outdoors, experiencing the contrast of sea and mountains and local cuisine and wine tourism.

Theme programmes of religious tourism can provide an incentive to satisfy cruise tourists' needs. Apart from visits to sacred sites and holy shrines in Sinj, Vepric near Makarska, Zaostrog, even a trip to Međugorje can be complemented with a programme to get to know the local wine and cuisine culture. Wine is increasingly becoming a reason for tourist trips. The centuries old tradition of wine production and viticulture can be the basis for a wine route programme and wine tasting. Wine fields in the Split region include its' hinterland and areas of Imotski, Vrgorac and Makarska.

To implement the afore-mentioned programmes, requires considerably greater cooperation of local administration, public sector, tourist offices and other economic areas. Special measures and activities to affirm Split as a cruise destination begin with effective advertising on the cruise tourism market. Split's port authority in cooperation with tourist offices and the tourism sector of the town has carried out advertising activities on the cruising tourism market. Those activities mainly refer on attending specialised fairs for cruise tourism with modest financial investment in advertising campaigns and use of specialised media. The main insufficiency of advertising campaigns for cruise tourism in Split, apart from the modest budget for advertising, is the discrepancy of common activities without a formulated marketing strategy. Because of this, particular cooperation and organisation are necessary between tourist offices and travel agency institutions, that would create programmes and products for cruise tourism and particular advertising activities for cruise tourists. 
Only common activities can satisfy the needs of cruise tourists where Split as a cruise destination has exceptional developmental possibilities and in that way can become a full member of the association of European ports for cruises.

\section{Conclusions}

Cruise tourism as a part of mass tourism movements of global proportions is also focused,to a certain level, on the Adriatic coast, where Split and its' port are becoming interesting place.

In satisfying tourists' needs on cruise ships that arrive in Split, a certain structure of supply has been formed, which is not on appropriate level, neither according to diversity nor quality. Considering increase in the arrivals of cruise ships and cruise tourists over the last years, certain activities have been undertaken by the City of Split that would increase the entire offer for cruise tourism. Apart from increasing operative capacity of the port of Split, the tourist sector above all travel agencies, are undertaking certain activities to create new programmes that would satisfy the needs of cruise tourists. However, those programmes, which are aimed at stationary tourism, are only adapted partly to the needs of cruise tourists that visit Split. This mainly applies to the modest town sightseeing programme (Diocletian's Palace, museums, and galleries) and trips to the surrounding area of Split (Salona, Trogir, and the Cetina River Canyon). Given that cruise tourism creates additional incentives to the increase of spending and creation of additional positive effects on the town's economy and its' wider area's economy, it is necessary to establish a completely new concept of development of the tourist offer for this type of tourism. It is necessary to establish a model of organisation which will unite local administration, town council's organisation, port and port authority, tourist offices, business subjects from transport and retail with the particular involvement of travel agencies and the tourist sector. These interest groups should be the creators of operative developmental and marketing strategies for cruising tourism in Split. Only under these conditions, Split can improve its' position on the international cruise tourism market, and can become a full and proper member of the association of specialised European ports for cruise journeys.

\section{References}

Britton, S. (1991). Tourism, Capital and place: Towards a Critical Geography of Tourism. Environment and Planning D: Society and Space, 4, 451-478.

Cartwright, R., Baird, C. (1999). The Development and Growth of the Cruise Industry. Oxford: Butterworth Heinemann. Chin, C.B.N. (2008). Cruising in the Global Economy. Hampshire: Ashgate.

Coles, T., Hall. M. (eds.) (2008). International Business and Tourism; Global Issues, Contemporary Interactions. London: Routledge.

Dickinson, B., Vladimir, A. (1997). Selling the Sea: An Inside Look at the Cruise Industry. New York: John Wiley \& Sons.

Institut za turizam Stavovi i potrošnja putnika i članova posade na kružnim putovanjima brodom u Hrvatskoj u 2006 godini (2006). TOMAS Brodska kružna putovanja.

MacCannell, D. (1989). The Tourist: A New Theory of Leisure Class. New York: Schocken.

Ritzer, G., Liska, A. (1997). 'McDisneyization' and. 'Post-Tourism': Complementary Perspective on Contemporary Tourism. In: C. Rojek, J. Urry (eds.), Touring Cultures: Transformations of Travel and Theory. London: Routledge. 
Šaban, M. (2015). Uloga kruzerskog turizma u razvoju suvremenog turizna Grada Splita. Sveučilište u Zadru Odjel za turizam i komunikacijske znanosti, Zadar.

Stavovi i potrošnja turista u Hrvatskoj (2011). TOMAS ljeto 2010. Institut za turizam.

Studija održivog razvoja kruzing turizma u Hrvatskoj (2007). Zagreb: Institut za turizam.

Teye, V., Leclerc, D. (1998). Product and service delivery satisfaction among North American cruise passengers. Tourism Management, 19 (2), 153-160.

Urry, J. (2002). The Tourist Gaze, 2nd Edition. London: Sage.

Weaver, A., Duval, T.D. (2008). International and transnational aspects of the global cruise industry (pp. 106-123). In: T. Coles, M. Hall (eds.), International Business and Tourism. London: Routledgle.

Wood, R.E. (2004). Caribbean of the East? Global Interconnections and the Southeast Asian Cruise Industry. Asian Journal of Social Science, 30 (2), 420-440.

www.europeancruisecouncil.com (25.05.2015).

www.portsplit.com (11.05.2015).

\section{ZNACZENIE CRUSINGU W ROZWOJU TURYSTYKI W SPLICIE}

SŁOWA KLUCZOWE

STRESZCZENIE crusing, popyt turystyczny, destynacja turystyczna, podaż turystyczna

Głównym celem artykułu jest pokazanie wpływu crusingu na poprawę wizerunku i marki Splitu oraz przedstawienie jego wpływu na wydłużenie sezonu turystycznego. Miasto Split wraz z kilkoma innymi portami w basenie Morza Śródziemnego ma szanse oprzeć swój rozwój na crusingu i stać się rozpoznawalne jako międzynarodowy cel wyjazdów tego typu. Wzrost liczby turystów, korzystających z tej współczesnej formy turystyki przyczynia się bowiem do rozwoju nowych form podaży turystycznej oraz wydłużania sezonu turystycznego. 